\title{
Hydraulic Analysis of Biochannels for Sustainable Urban Drainage Systems
}

\author{
Muhamad Nurfasya Alias ${ }^{1}$, Muhammad Mujahid Muhammad ${ }^{2}$, Khamaruzaman Wan Yusof $^{2}$, Muhammad Raza UI Mustafa ${ }^{2}$, \\ and Aminuddin Ab. Ghani ${ }^{1}$ \\ ${ }^{1}$ River Engineering and Urban Drainage Research Centre (REDAC), Universiti Sains Malaysia (USM), Malaysia \\ ${ }^{2}$ Civil \& Environmental Engineering Department, Universiti Teknologi PETRONAS (UTP), Malaysia
}

\begin{abstract}
This study focuses on employing channel lining materials that includes Turf Reinforcements Mat (TRM) and Erosion Control Blanket (ECB) as bioengineering techniques for erosion control. Hydraulic characteristics of flow through these materials were determined in terms of flow velocities and shear stresses. The experimental results indicated that the average velocity for TRM ranges between 0.6 to $3.5 \mathrm{~m} / \mathrm{s}$, while that of ECB varies from 0.7 to 4.1 $\mathrm{m} / \mathrm{s}$. Also, TRM has shear stress values of $1.950 \mathrm{~N} / \mathrm{m}^{3}$ for bed and $1.575 \mathrm{~N} / \mathrm{m}^{3}$ for bank respectively of test channel when the flow depth was $15 \mathrm{~cm}$. While ECB has shear stresses of $2.138 \mathrm{~N} / \mathrm{m} 3$ for bed and $1.721 \mathrm{~N} / \mathrm{m}^{3}$ for bank for same flow depth of $15 \mathrm{~cm}$. However, when the flow depth is $5 \mathrm{~cm}$, TRM has values of $0.972 \mathrm{~N} / \mathrm{m}^{3}$ for bed and 0.769 $\mathrm{N} / \mathrm{m}^{3}$ for bank, and ECB gives $0.957 \mathrm{~N} / \mathrm{m}^{3}$ for bed and $0.766 \mathrm{~N} / \mathrm{m}^{3}$ for bank of test channel. Hence, the greater the flow depth, the higher the velocities and shear stresses respectively. Conversely, lower flow depths lead to velocities and shear stresses that are within the allowable standards for designing a stable channel. Generally, TRM performed the best for having higher shear stresses compared to ECB.
\end{abstract}

\section{Introduction}

Bioengineering is a construction method of using living plant or plants combined with dead or organic materials. The practice results in the combined use of biological, ecological and engineering concepts to produce a living, functioning system to prevent erosion and provide particulate contaminant removal through sedimentation and soil infiltration, and improves the aesthetics of a site $[1,2]$. In addition, natural vegetation can be applied on hilly land surfaces to increase slope stability against failure due to erosion by rainfall. Erosion occurs when the hydraulic forces in the flow exceed the resisting forces of the channel boundary. The amount of erosion is a function of the relative magnitude of these forces and the time over which they are applied. The interaction of flow with the boundary of open channels is only imperfectly understood [3].

The use of plants for river bank protection and erosion control has a long tradition in Europe. Recently, existing bank erosion and stabilization techniques have been rediscovered and improved [4]. These old techniques have been rediscovered and improved in the first half of nineteenth century, with new technical and biological knowledge. Today, there is a variety of bioengineering techniques available to suit different situations and requirements. Biotechnical engineering techniques have become part of geotechnical and hydraulic engineering and have helped bridge the gap between classical engineering disciplines, land use management, landscape architecture and biological sciences [5].

These biotechnical engineering (bioengineering) techniques are developed by a system of trial and error. Most of these techniques are based on long-term practical experience. These "soft" engineering practices can provide possibilities to complement and improve or in some cases even replace traditional "hard" river-training constructions, such as placement of gabions or rock. These also offer a more ecologically acceptable way of bank stabilization that still compiles the land use and safety requirements.

Many governmental agencies favored stone or concrete riprap because over time, a high degree of precision and confidence in construction has developed from research and analysis. In engineering viewpoints, these techniques have been successful or their immediate protections of properties or infrastructure adjacent to the stream after projects were completed. What was thought successful in the past is being reevaluated in context of impacts resulting from excessive and rapid urbanization, and public awareness of these new environmental issues. Increasing failures of traditional channelization and armoring techniques are generating questions as to whether traditional practices are appropriate in every setting [6]. The interest in natural techniques called biotechnical engineering was raised, and the benefits and advantages of biotechnical engineering were gradually reexamined [7]. 
The purpose of this study was to investigate the effectiveness and applicability of bioengineering techniques for bank stability and protection against erosion as a viable alternative to traditional channelization and hard armoring techniques. Also, the suitability of the technique was assessed which can be used in urban environments like Malaysia.

\section{Theoretical concepts}

\subsection{Vertical velocity profiles}

Velocity varies approximately as a parabola from zero at the channel bottom to a maximum near the surface. A typical vertical velocity profile is shown in Figure 1. It has been determined empirically that for most channels the velocity at six-tenths of the total depth below the surface is a close approximation to the mean velocity at that vertical line. However, the average of the velocities at two-tenths and eight-tenths depth below the surface on the same vertical line provides a more accurate value of mean velocity at that vertical line.

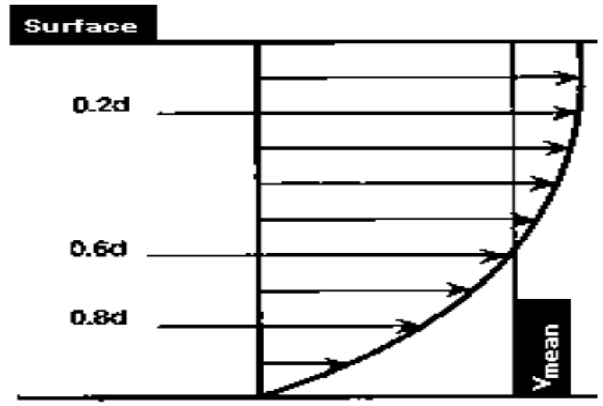

Figure 1. Typical river velocity profile in the vertical plane.

\subsection{Channel stability}

Two basic types of lining classes are rigid linings such as concrete, and flexible linings such as rock rip raps, rock mattresses, and all RECPs [8, 9]. Rigid linings are nonerodible, permanent and long life, but they are susceptible to failure from foundation instability and unreliable hydraulic pressure release. Construction of rigid linings requires specialised equipment and costly materials. As a result, the cost of rigid channel linings is typically higher than an equivalent flexible channel lining[8].

The stability of a channel or the suitability of various channel linings can be determined by first calculating both the mean velocity and tractive stress. Additionally, product literatures from manufacturers can provide information on allowable tractive stresses or velocities for various types of erosion control products. A general procedure for designing a stable channel has been presented by Fischenich [3]. Thus, after estimating the mean hydraulic conditions, the shear stress may be computed, for example, the local maximum shear stress, $\tau_{\max }$, for straight channels can be calculated from the following simple equation (1):

$$
\tau_{\max }=1.5 \tau
$$

For sinuous channels, the maximum shear stress, $\tau$ ${ }_{\text {max }}^{*}$, should be determined as a function of the platform characteristics using Equation (2):

$$
\tau_{\max }^{*}=2.65 \tau\left(R_{c} / W\right)^{-0.5}
$$

where, $R_{c}=$ Radius of curvature $(m)$ and $W=$ Top width of the channel (m).

Moreover, existing stability should be assessed by comparing estimates of local and instantaneous shear and velocity to values. If the existing conditions are deemed stable and are in consonance with other project objectives, then no further action is required. Otherwise recomputed flow values, Table 1 presents velocity limits for various channel boundaries conditions, while in order to account for flow duration Figures 2 and 3 may be used as a guide.

Table 1. Stability of channel linings for given velocity range by fischenich [3].

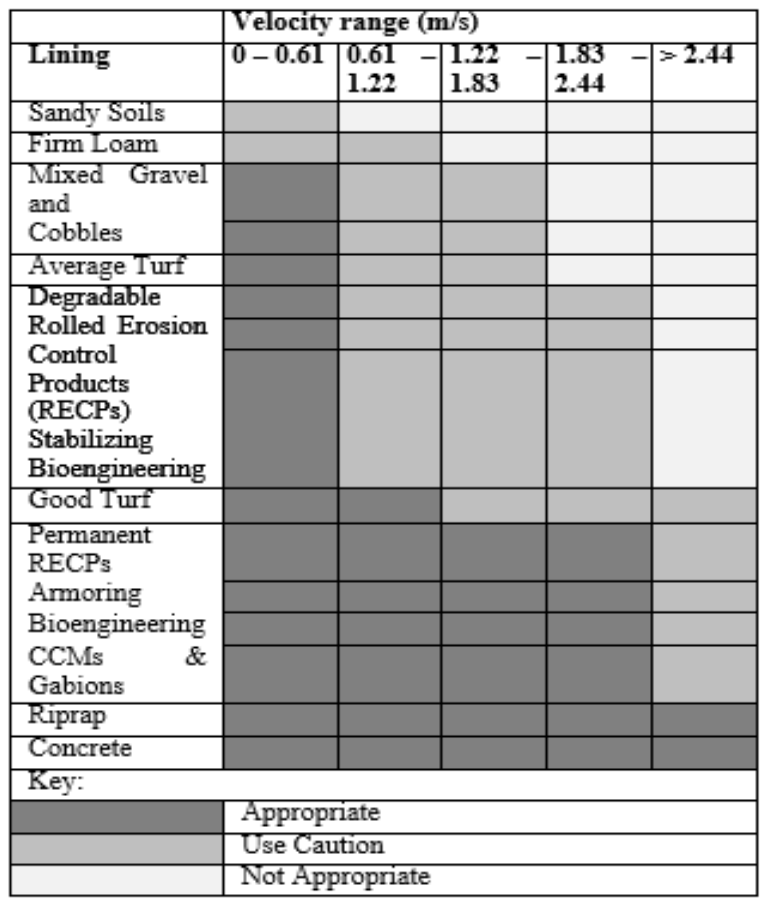

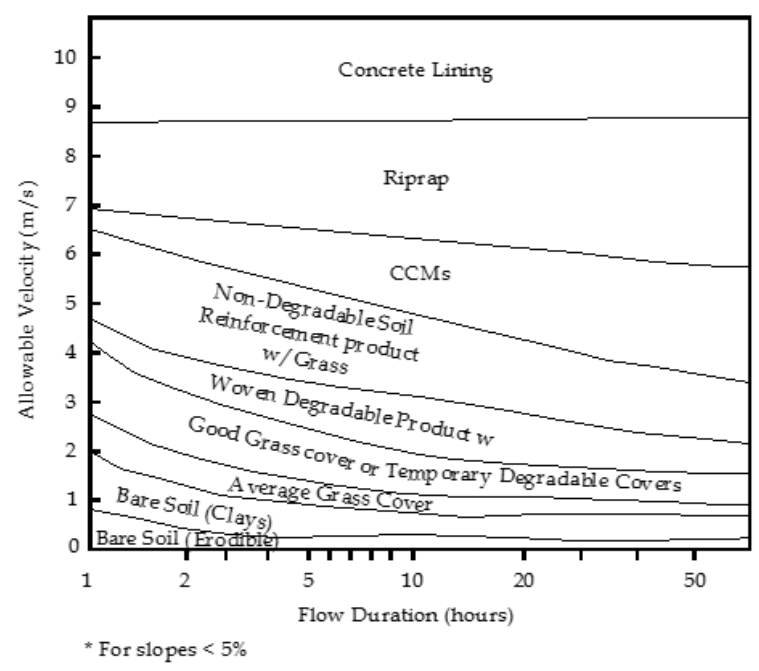

Figure 2. Erosion limits as a function of flow duration by Fischenich and Allen [10]. 

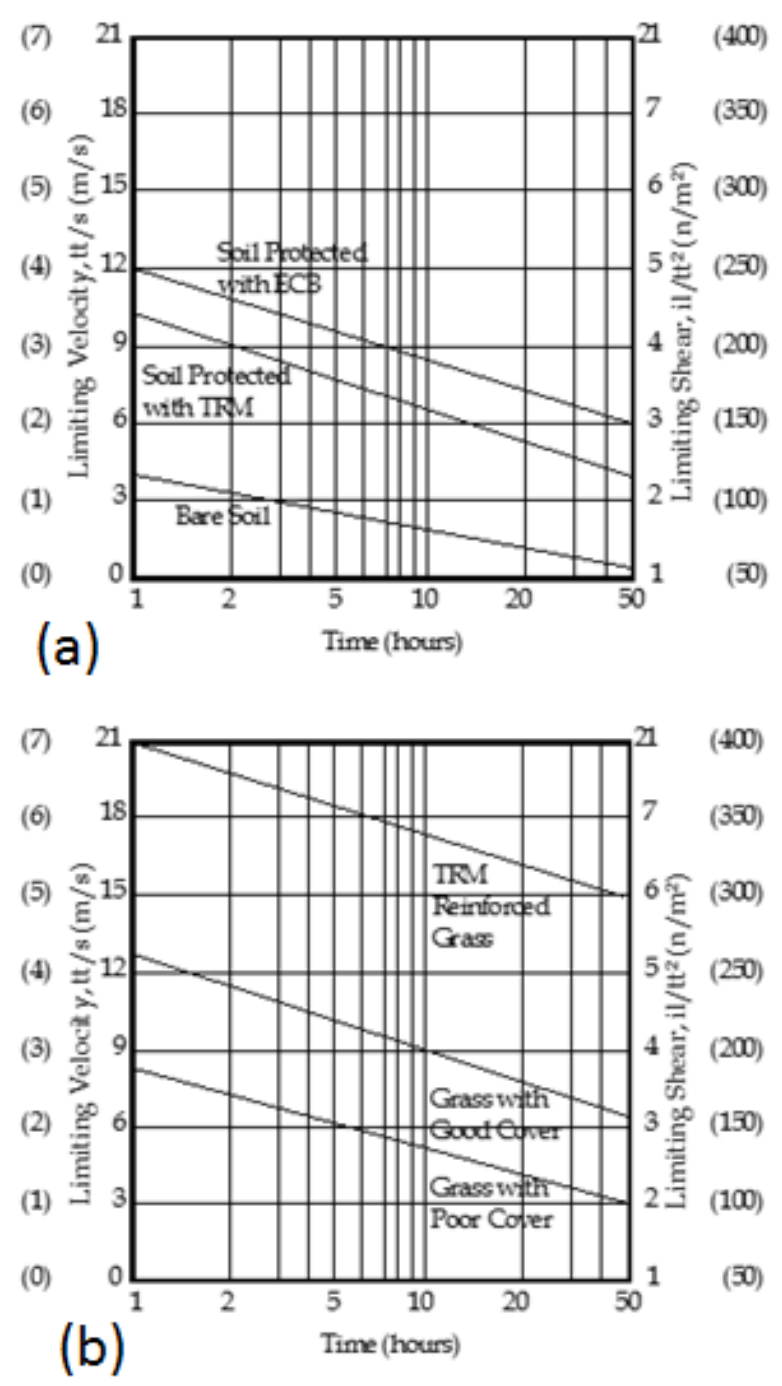

Figure 3. Limiting value for velocity and shear for (a) Bare soil, TRM and ECB ; (b) Grass and/or TRM [11].

\subsection{Shear stress on streambed and banks}

On any given bank, the material and vegetation types required to resist erosion may vary with location. Lane's diagram, Figure 4, shows theoretical distribution of shear stress on streambed and banks on a straight section of trapezoidal channel. Based on Lane's diagram, materials and plants of greater shear resistance are required lower on the bank, while a lighter-duty treatment may be sufficient near the top of the bank.

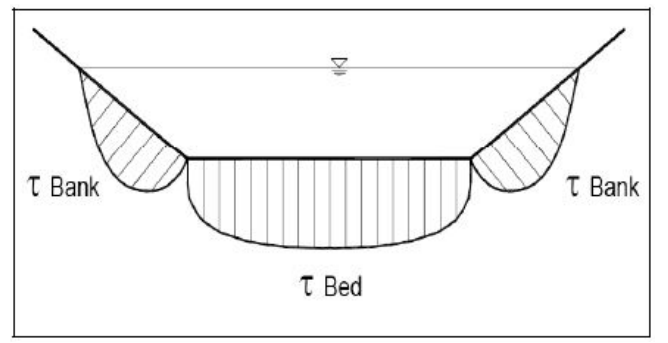

Figure 4. Distribution of shear stress on streambed and banks.

Shear stress is an important parameter in habitat rehabilitation design, because all materials, whether manufactured or natural, used for habitat rehabilitation must be able to withstand the expected shear stress at the design discharge [12].

A common application of the equation for maximum shear stress in a straight reach will be apply for streambed and bank of the test channel. For maximum shear stress on the bed is:

$$
\begin{gathered}
\tau_{\text {bed }}=\gamma R S=\gamma(A / P) S \\
\tau_{\text {bed }}=9806 R S
\end{gathered}
$$

where, $\tau_{\text {bed }}=$ maximum bed shear stress $\left(\mathrm{N} / \mathrm{m}^{2}\right), \gamma=$ the specific weight of water $\left(\mathrm{N} / \mathrm{m}^{3}\right), \mathrm{R}=$ hydraulic radius in $\mathrm{m}, \mathrm{A}=$ flow cross-sectional area $\left(\mathrm{m}^{2}\right), \mathrm{P}=$ wetted perimeter ( $\mathrm{m}$ ) and $\mathrm{S}=$ energy slope.

This calculation gives a quantitative measure of the erosive force acting on the bed of the channel.

By approximating the channel cross-section as a trapezoid or rectangular, the maximum bed shear stress can be used to estimate the maximum bank shear stress. This stress acts approximately one-third of the distance up the bank (from the bed) and can be approximated by multiplying the maximum bed shear stress by a factor (see Lane's Diagram, Figure 5). This factor, $\mathrm{K}_{1}$, varies based on channel side slope and the ratio of bottom width to depth as shown in Figure 5. This approximation applies only to a relatively straight channel reach.

For maximum shear stress, $\tau_{\text {bank, }}$ on the bank is:

$$
\tau_{\text {bank }}=K_{1} \tau_{\text {bed }}
$$

where, $\tau_{\text {bed }}=$ maximum bed shear stress $\left(\mathrm{N} / \mathrm{m}^{2}\right)$ and $\mathrm{K}_{1}=$ ratio obtained from Figure 5 . It should be noted that $\tau_{\text {bed }}$ is estimated by knowing the aspect ratio width (B) divide by flow depth $(\mathrm{d})=\mathrm{B} / \mathrm{d}$ and the side slope $\mathrm{z}$ using Figure 5 as well.

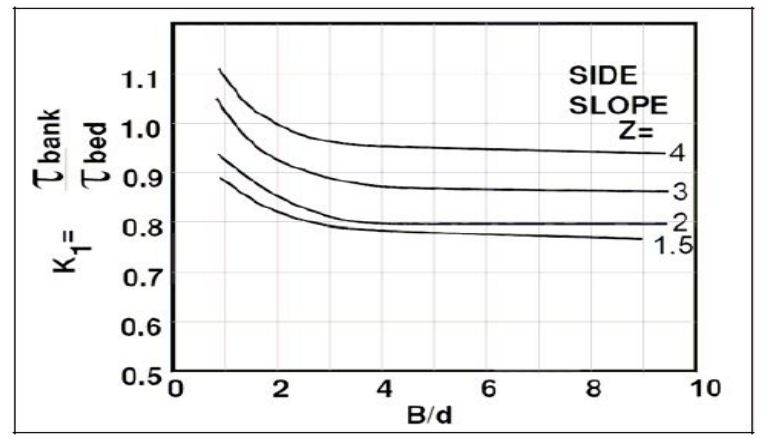

Figure 5. Coefficient $K_{1}$ vs. side slope $z$, and width/depth B/d ratio.

\section{Methodology}

\subsection{Selection of the bioengineering materials for channel bank stabilization}

Two (2) types of channel lining materials of bioengineering technique such as Turf Reinforcement Mat (TRM) and Erosion Control Blanket (ECB) were selected in this study. Both products were designed for erosion protection and the establishment of vegetation up 
to 12 months. Others technical specification for both selected material are presented in Table 2.

Table 2. Technical specification of tested material (fibromat).

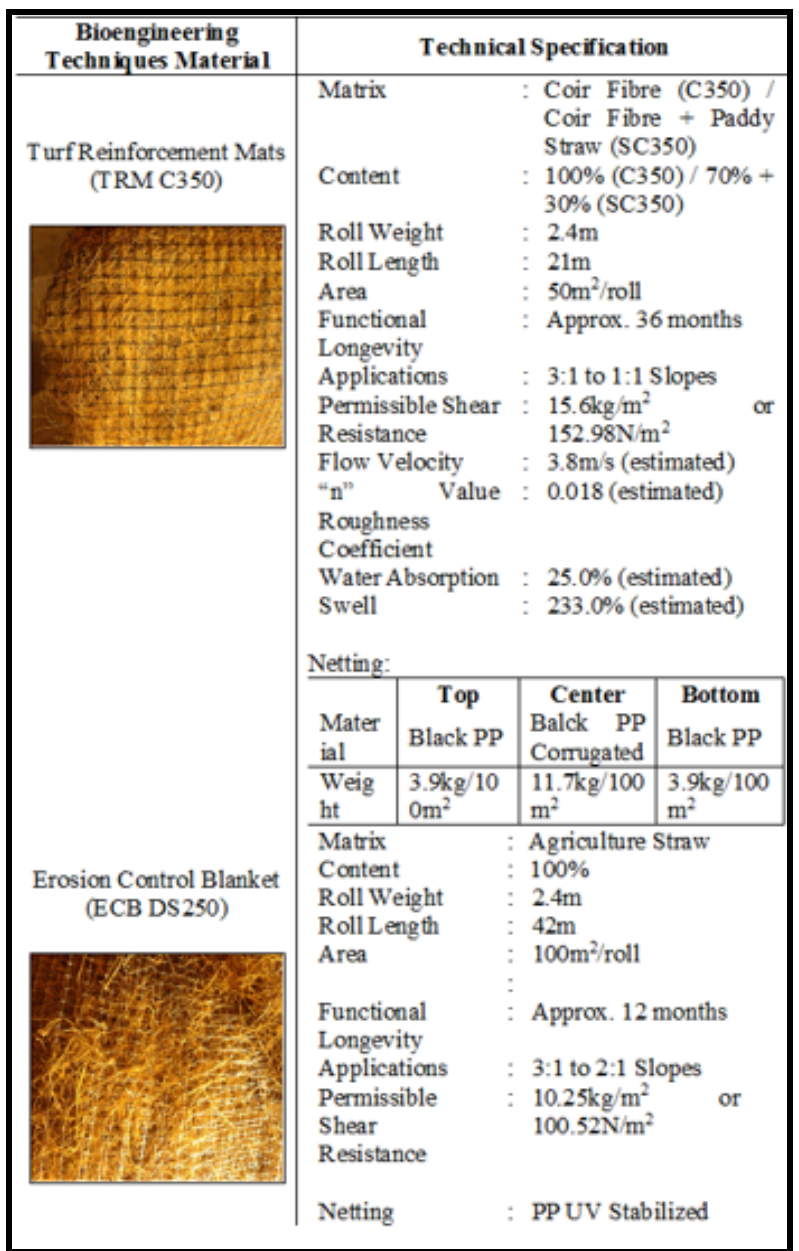

\subsection{Design considerations of the test channel}

The channel for this research project was constructed by using the design criteria as follows:

Bed slope, $\mathrm{So}=1 / 500$ or 0.002

Channel bank slopes $=1: 2$ (left bank of the channel) and 1:1 (right bank of the channel)

Channel length $=10 \mathrm{~m}$

Channel cross section $=$ Trapezoidal

Bottom width $=0.6 \mathrm{~m}$

Top width $=2.1 \mathrm{~m}$

Depth $=0.5 \mathrm{~m}$

After preparing the platform and backfilling the channel cross section with soil, Figure 6 (a) - (f) shows the laying works of lining material on the soil surface in the proposed test channel.

\subsection{Cross section measurements}

Bank full width method was used in order to get the cross section profile of the test channel. A tape measure been stretched from one bank to the other at $90^{\circ}$ to the course of the channel. Figure 7 shows the measuring works of test channel cross section, which represents the measurement locations of the cross section profile at $1 \mathrm{~m}$ intervals from the channel inlet, with $\mathrm{CH} 0.0, \mathrm{CH} 1.0, \mathrm{CH}$ 2.0, $\mathrm{CH} 3.0, \mathrm{CH} 4.0, \mathrm{CH} 5.0$ and $\mathrm{CH} 6.0$ denoting $0 \mathrm{~m}, 1$ $\mathrm{m}, 2 \mathrm{~m}, 3 \mathrm{~m}, 4 \mathrm{~m}, 5 \mathrm{~m}$ and $6 \mathrm{~m}$ respectively.

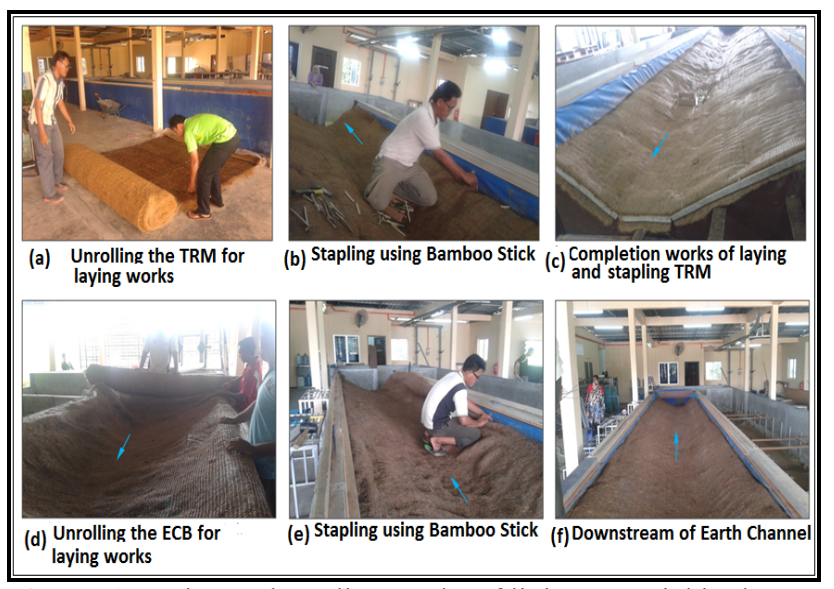

Figure 6. Laying and stapling works of lining material in the proposed test channel.

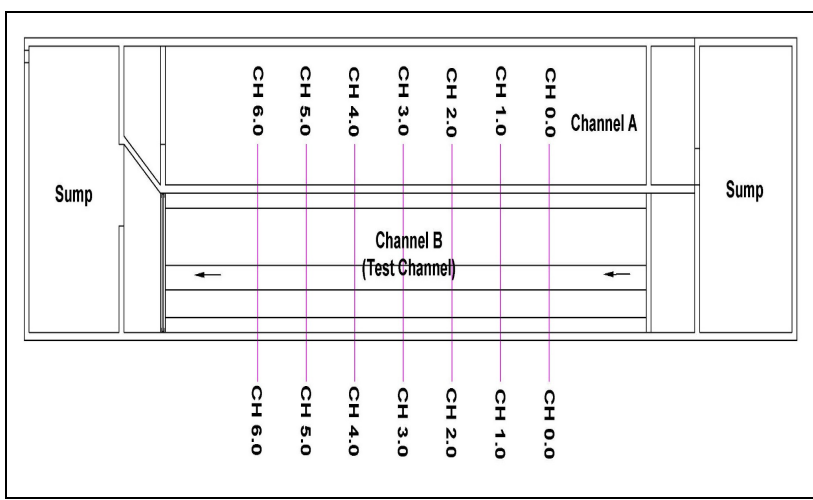

Figure 7. Plan view of test channel showing measurement locations.

\subsection{Experimental procedure for testing the bioengineering materials}

The water was pumped into the test channel from the existing overhead water tank. An underground sump was to collect and store the water from channel before it is being circulated to the water tank. Figure 8 (a) - (b) shows the flow of water through the test channel.

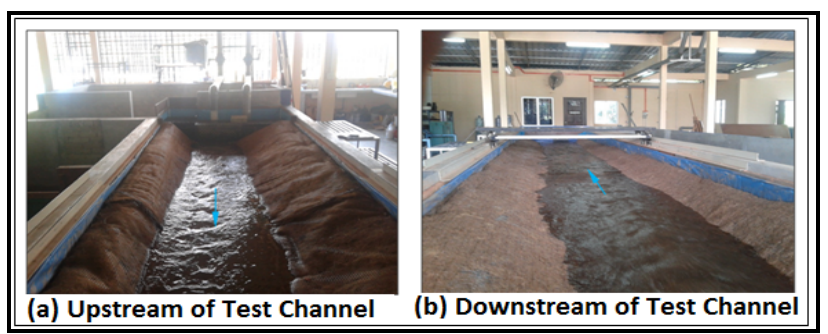

Figure 8. Water flow through the test channel.

Due to the occurrence of backwater in the channel length, only $4 \mathrm{~m}$ length at the middle part of the test channel was used for testing. Velocities of test channel were measured by using flow meter. Three (3) different depths were used to measure flow characteristics in the test channel. These depths comprised $5 \mathrm{~cm}, 10 \mathrm{~cm}$ and $15 \mathrm{~cm}$. Three (3) readings for vertical velocity were 
recorded by using a current meter and then average values computed for each cross section.

Afterwards the discharge, Q, was estimated by the velocity - area method, which was derived from $\mathrm{Q}=\mathrm{VA}$, where, $\mathrm{V}$ is the measured average velocity and $\mathrm{A}$, being the cross sectional area. Then Manning's roughness, $n$, in Tables 3 and 4 were calculated using Manning's equation (6), which, although developed for conditions of uniform flow in open channels, may give an adequate estimate of the non-uniform flow which is usual in natural channels. The Manning equation states that:

$$
Q=\left(A R^{2 / 3} S^{1 / 2}\right) / n
$$

where, $Q=$ discharge $\left(\mathrm{m}^{3} / \mathrm{s}\right), A=$ cross-sectional area $\left(\mathrm{m}^{2}\right), R=$ hydraulic $\operatorname{radius}(\mathrm{m})=\mathrm{A} / \mathrm{P}, P=$ wetted perimeter $(\mathrm{m})$, and $S=$ slope of gradient of the bed.

\section{Results and discussion}

\subsection{Cross section profiles of test channel}

Figures $9 \mathrm{a}$ and $9 \mathrm{~b}$ show the cross sectional profiles of the test channel at different chains along the channel length. Also, it depicts the maximum level in which water may rise.

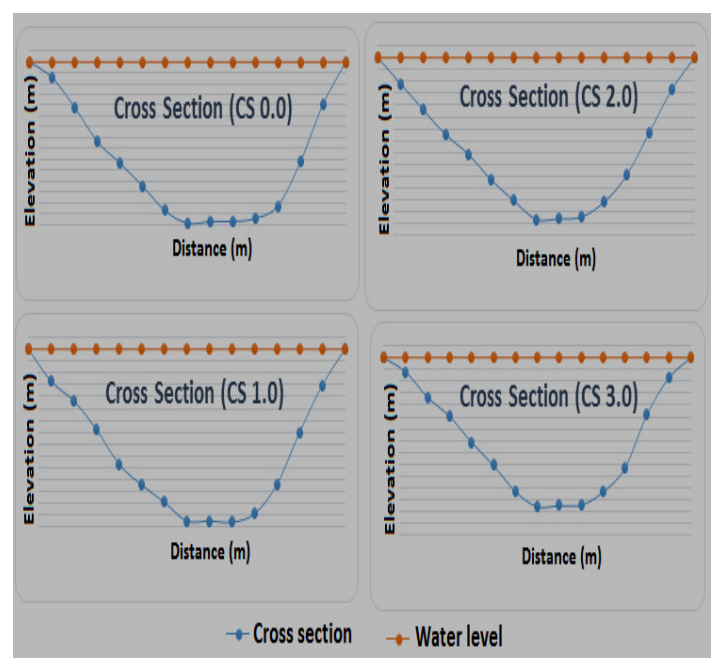

Figure 9a. Cross sectional profiles at $0 \mathrm{~m}, 1 \mathrm{~m}, 2 \mathrm{~m}$ and $3 \mathrm{~m}$ along the test channel.

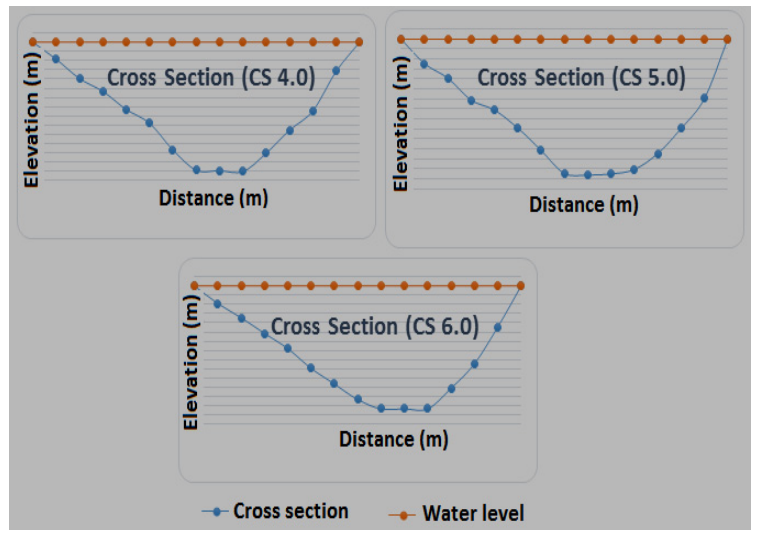

Figure 9b. Cross sectional profiles at $4 \mathrm{~m}, 5 \mathrm{~m}$, and $6 \mathrm{~m}$ along the test channel.

\subsection{Flow parameters}

Starting with TRM test channel, from Table 3, the average vertical velocity for $5 \mathrm{~cm}$ depth recorded was in the range of $0.6 \mathrm{~m} / \mathrm{s}$ to $1.2 \mathrm{~m} / \mathrm{s}$. The average vertical velocity for $10 \mathrm{~cm}$ depth recorded falls between $1.6 \mathrm{~m} / \mathrm{s}$ to $1.9 \mathrm{~m} / \mathrm{s}$. While the average vertical velocity for $15 \mathrm{~cm}$ depth recorded varies from $3.1 \mathrm{~m} / \mathrm{s}$ to $3.5 \mathrm{~m} / \mathrm{s}$. Similarly, from Table 4, for ECB test channel, the average vertical velocity for $5 \mathrm{~cm}$ depth recorded falls between $0.7 \mathrm{~m} / \mathrm{s}$ to $1.4 \mathrm{~m} / \mathrm{s}$. The total average vertical velocity for $10 \mathrm{~cm}$ depth recorded were within $1.5 \mathrm{~m} / \mathrm{s}$ to $2.7 \mathrm{~m} / \mathrm{s}$. While the average vertical velocity for $15 \mathrm{~cm}$ depth recorded varies from $3.2 \mathrm{~m} / \mathrm{s}$ to $4.1 \mathrm{~m} / \mathrm{s}$.

Table 3. Total average vertical velocity and flow for TRM test channel.

\begin{tabular}{|c|c|c|c|c|c|}
\hline \multirow[b]{2}{*}{$\begin{array}{c}\text { Lining } \\
\text { Material }\end{array}$} & \multirow[b]{2}{*}{$\begin{array}{c}\text { Flow } \\
\text { Depth } \\
(\mathbf{c m})\end{array}$} & \multirow[b]{2}{*}{$\begin{array}{c}\text { Cross } \\
\text { Section } \\
\text { (CH m) }\end{array}$} & \multicolumn{2}{|c|}{ Total } & \multirow[b]{2}{*}{ Manning's } \\
\hline & & & $\begin{array}{c}\text { Average } \\
\text { Vertical } \\
\text { Velocity, } \\
\mathbf{v} \\
(\mathrm{m} / \mathrm{s})\end{array}$ & $\begin{array}{c}\text { Flow, } \\
\mathbf{Q} \\
\left(\mathrm{m}^{3} / \mathrm{s}\right)\end{array}$ & \\
\hline \multirow{18}{*}{ 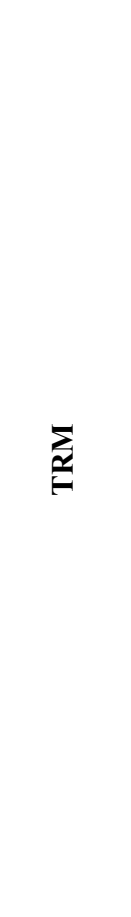 } & \multirow{6}{*}{5.0} & 0.00 & 0.772 & 0.0050 & 0.025 \\
\hline & & 1.00 & 0.647 & 0.0033 & 0.039 \\
\hline & & 2.00 & 0.760 & 0.0040 & 0.037 \\
\hline & & 3.00 & 0.920 & 0.0049 & 0.019 \\
\hline & & 4.00 & 1.172 & 0.0062 & 0.015 \\
\hline & & Total & 4.270 & 0.0234 & $\begin{array}{l}\text { Mean } \\
\text { 0.027 }\end{array}$ \\
\hline & \multirow{6}{*}{10.0} & 0.00 & 1.840 & 0.0206 & 0.018 \\
\hline & & 1.00 & 1.823 & 0.0183 & 0.020 \\
\hline & & 2.00 & 1.893 & 0.0173 & 0.021 \\
\hline & & 3.00 & 1.693 & 0.0157 & 0.024 \\
\hline & & 4.00 & 1.697 & 0.0179 & 0.028 \\
\hline & & Total & 8.947 & 0.0898 & $\begin{array}{l}\text { Mean } \\
\text { 0.022 }\end{array}$ \\
\hline & \multirow{6}{*}{15.0} & 0.00 & 3.160 & 0.0451 & 0.014 \\
\hline & & 1.00 & 3.470 & 0.0436 & 0.013 \\
\hline & & 2.00 & 3.400 & 0.0453 & 0.014 \\
\hline & & 3.00 & 3.857 & 0.0439 & 0.014 \\
\hline & & 4.00 & 3.453 & 0.0458 & 0.013 \\
\hline & & Total & 17.340 & 0.2237 & $\begin{array}{l}\text { Mean } \\
\text { 0.014 }\end{array}$ \\
\hline
\end{tabular}

Table 4. Total average vertical velocity and flow for ECB test channel.

\begin{tabular}{|c|c|c|c|c|c|}
\hline \multirow[b]{2}{*}{$\begin{array}{c}\text { Lining } \\
\text { Material }\end{array}$} & \multirow[b]{2}{*}{$\begin{array}{c}\text { Flow } \\
\text { Depth } \\
\text { (cm) }\end{array}$} & \multirow[b]{2}{*}{$\begin{array}{c}\text { Cross } \\
\text { Section } \\
\text { (CH } \\
\text { m) }\end{array}$} & \multicolumn{2}{|c|}{ Total } & \multirow[b]{2}{*}{$\begin{array}{c}\text { Manning's } \\
\text { n }\end{array}$} \\
\hline & & & $\begin{array}{c}\text { Average } \\
\text { Vertical } \\
\text { Velocity, } \\
\mathbf{v} \\
(\mathrm{m} / \mathrm{s})\end{array}$ & $\begin{array}{c}\text { Flow, } \\
\mathbf{Q} \\
\left(\mathbf{m}^{3} / \mathbf{s}\right)\end{array}$ & \\
\hline \multirow{7}{*}{$\bigcup_{\text {令 }}^{\infty}$} & \multirow{6}{*}{5.0} & 0.00 & 0.783 & 0.0059 & 0.033 \\
\hline & & 1.00 & 1.007 & 0.0051 & 0.024 \\
\hline & & 2.00 & 0.780 & 0.0031 & 0.033 \\
\hline & & 3.00 & 0.782 & 0.0032 & 0.028 \\
\hline & & 4.00 & 1.347 & 0.0061 & 0.014 \\
\hline & & Total & 4.698 & 0.0234 & Mean 0.026 \\
\hline & 10.0 & 0.00 & 1.533 & 0.0179 & 0.024 \\
\hline
\end{tabular}




\begin{tabular}{ccccc} 
& 1.00 & 1.360 & 0.0117 & 0.026 \\
& 2.00 & 1.893 & 0.0130 & 0.018 \\
3.00 & 2.107 & 0.0121 & 0.018 \\
& 4.00 & 2.677 & 0.0164 & 0.012 \\
\hline \multirow{6}{*}{15.0} & Total & $\mathbf{9 . 5 7 0}$ & $\mathbf{0 . 0 7 1 1}$ & Mean 0.019 \\
\hline \multirow{6}{*}{} & 0.00 & 4.090 & 0.0683 & 0.013 \\
& 1.00 & 3.283 & 0.0479 & 0.017 \\
& 2.00 & 3.670 & 0.0526 & 0.013 \\
& 3.00 & 3.597 & 0.0471 & 0.015 \\
& 4.00 & 3.990 & 0.0515 & 0.012 \\
\cline { 2 - 5 } & Total & $\mathbf{1 8 . 6 3 0}$ & $\mathbf{0 . 2 6 7 3}$ & Mean $\mathbf{0 . 0 1 4}$ \\
\hline
\end{tabular}

\subsection{Shear stress for the channel lining materials}

The flow depth of $15 \mathrm{~cm}$ gives the highest values of estimated shear stress for both lining materials. The experiment conducted for TRM lining material gives $1.950 \mathrm{~N} / \mathrm{m}^{3}$ for bed and $1.575 \mathrm{~N} / \mathrm{m}^{3}$ for bank of test channel. While for ECB lining material gives $2.138 \mathrm{~N} / \mathrm{m}^{3}$ for bed and $1.721 \mathrm{~N} / \mathrm{m}^{3}$ for bank of test channel. The flow depth of $5 \mathrm{~cm}$ gives the lowest values of estimate shear stress for both lining materials. Lining material of TRM gives the values $0.972 \mathrm{~N} / \mathrm{m}^{3}$ for bed and $0.769 \mathrm{~N} / \mathrm{m}^{3}$ for bank of test channel. While lining material of ECB gives the values $0.957 \mathrm{~N} / \mathrm{m}^{3}$ for bed and $0.766 \mathrm{~N} / \mathrm{m}^{3}$ for bank of test channel. Table 5 shows the summary of average shear stress for test channel bed and bank. Also, Figure $10 \& 11$ show the variations of shear stresses with the aspect ratio $(\mathrm{B} / \mathrm{y})$. As the aspect ratio decreases the shear stresses increases and vice versa in the both test materials.

Table 5. Average shear stress for test channel bed and bank.

\begin{tabular}{|c|c|c|c|c|}
\hline \multirow[b]{2}{*}{$\begin{array}{l}\text { Lining } \\
\text { Material }\end{array}$} & \multicolumn{4}{|c|}{ Parameter } \\
\hline & $\begin{array}{l}\text { Flow } \\
\text { Depth } \\
\text { (cm) }\end{array}$ & $\begin{array}{l}\mathrm{B} / \mathrm{y} \\
\text { (Average) }\end{array}$ & $\begin{array}{l}\tau_{\mathrm{b}} \\
\left(\mathbf{N} / \mathbf{m}^{3}\right)\end{array}$ & $\begin{array}{c}\tau_{\mathrm{s}} \\
\left(\mathbf{N} / \mathbf{m}^{3}\right)\end{array}$ \\
\hline \multirow{3}{*}{ TRM } & 5 & 8.071 & 0.972 & 0.769 \\
\hline & 10 & 6.096 & 1.568 & 1.262 \\
\hline & 15 & 4.861 & 1.950 & 1.575 \\
\hline \multirow{3}{*}{ ECB } & 5 & 7.525 & 0.957 & 0.766 \\
\hline & 10 & 5.113 & 1.418 & 1.139 \\
\hline & 15 & 4.467 & 2.138 & 1.721 \\
\hline
\end{tabular}

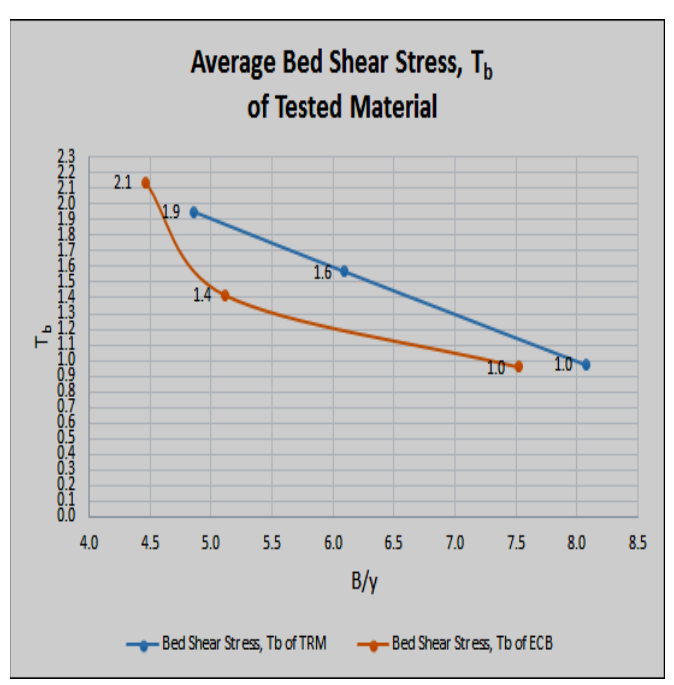

Figure 10. Average bed shear stress for tested material.

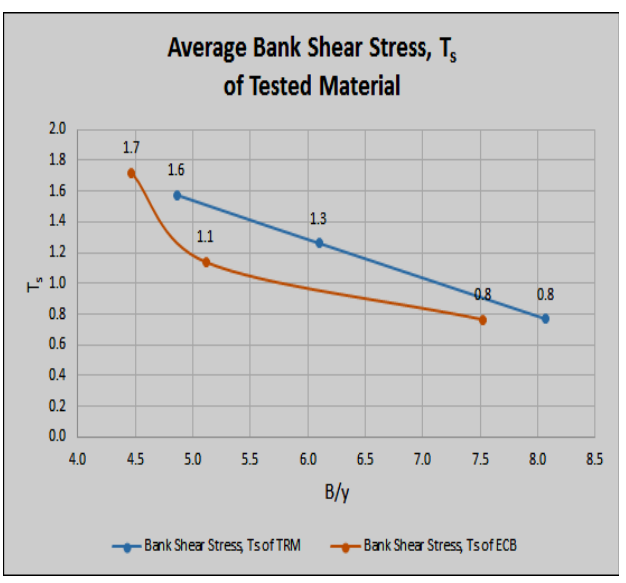

Figure 11. Average bank shear stress for tested material.

\section{Conclusion}

Within the limit of experimental error it can be concluded that both the average vertical velocities and estimated shear stresses of the different flow depths, show that the greater the flow depth, the higher would be the values of velocity and shear stress for both TRM and ECB materials respectively. Therefore, at low flow depths the hydraulic parameters obtained are within the allowable values and appropriate for designing a stable channel. Generally, TRM performed the best being having higher shear stress values compared to ECB.

Furthermore, investigation on combining TRM or ECB with green vegetation is required, as vegetation is more sustainable to erosion effects and eco-friendly to the environment.

\section{Acknowledgements}

The authors would like to acknowledge the short term grant from Universiti Sains Malaysia (Grant No. 304.PREDAC.60312035 / 1001.PREDAC.814225). The second author would also like to acknowledge Universiti Teknologi PETRONAS for the fellowship scheme to undertake the postgraduate study, and to as well the collaborative research with REDAC.

\section{References}

1. Department of Irrigation and Drainage Malaysia (DID). Urban Stormwater Management Manual for Malaysia, (2012)

2. Shahkolahi, A., Tadman, A. and Crase, J. An Economical Solution for Flood Protection and Channel Erosion Control. in Institute of Public Works Engineering Australiasia (IPWEA) Queensland Conference, (2014)

3. Fischenich, C. Stability thresholds for stream restoration materials, DTIC Document, (2001)

4. Evette, A., Labonne, S., Rey, F., Liebault, F., Jancke, O., Girel, J. History of bioengineering techniques for erosion control in rivers in Western Europe. Environmental Management, 43, 6 972-984 (2009) 
5. Donat, M. Bioengineering techniques for streambank restoration. A Review of Central European Practices. Vancouver, BC, Canada: Watershed Restoration Program. Ministry of Environment, Lands and Parks, and Ministry of Forests, (1995)

6. Li, M.-H. and K.E. Eddleman. Biotechnical engineering as an alternative to traditional engineering methods: A biotechnical streambank stabilization design approach. Landscape and Urban Planning, 60, 4 225-242 (2002)

7. Riley, A.L. Restoring streams in cities: A guide for planners, policymakers, and citizens, Island Press, (1998)

8. Kilgore, R.T. and G.K. Cotton, Design of roadside channels with flexible linings hydraulic engineering Circular Number 15, (2005)

9. Witheridge, G. Erosion and Sediment Control - A Field Guide for Construction Site Managers: Catchments and Creeks, P. Ltd, Editor, (2010)
10. Fishenich, C. and H. Allen. Stream Management, Water Operations Technical Support Program. US Army Corps of Engineers, Environmental Laboratory. Waterways Experiment Station. Vicksburg, MS, (2000)

11. Sprague, C. Green Engineering: Design Principles and Applications using Rolled Erosion Control products. Part Two. Civil Engineering News, 11, 2 (1999)

12. Saldi-Caromile, K., Bates, K., Skidmore, P., Barenti, J., and Pineo, D, Stream habitat restoration guidelines: Final draft. Washington Depts. of Fish and Wildlife and Ecology and the U.S. Fish and Wildlife Service. Editor Olympia, WA, (2004) 